ISSN: 1984-6266

\section{Principais impactos da Nova Norma Internacional de Arrendamento Mercantil sobre os indicadores econômico-financeiros das empresas aéreas GOL e LATAM.}

\author{
Luíza Lima Najar \\ UFRJ - Universidade Federal do Rio de Janeiro \\ luizalnajar@gmail.com \\ José Augusto Veiga da Costa Marques \\ UFRJ - Universidade Federal do Rio de Janeiro \\ joselaura@uol.com.br \\ Marcia da Silva Carvalho \\ UFRJ - Universidade Federal do Rio de Janeiro \\ marcia@facc.ufri.br \\ Leila Batista Mello \\ UFRJ - Universidade Federal do Rio de Janeiro \\ leilalbm63@gmail.com
}

\section{Recebimento: \\ $16 / 05 / 2018$ \\ Aprovação: \\ 24/05/2019}

\section{Editor responsável pela aprovação do artigo: \\ Dr. Flaviano Costa}

Editor responsável pela edição do artigo:

Dr. Flaviano Costa

Avaliado pelo sistema:

Double Blind Review

A reprodução dos artigos, total ou parcial, pode ser feita desde que citada a fonte.

\title{
Resumo
}

As regras de contabilização do arrendamento mercantil tem sido fonte de discussões pelo fato das arrendatárias na modalidade operacional não considerarem essas transações em seu balanço patrimonial, afetando a transparência das informações. Com a nova norma de arrendamento, IFRS 16, em princípio, essas operações passam a integrar as demonstrações contábeis de todas as arrendatárias. 0 objetivo deste estudo foi averiguar os principais efeitos dessa norma quando dado um tratamento contábil similar do arrendamento financeiro à classificação operacional, nos indicadores econômico-financeiros das organizações aéreas GOL e LATAM, nos exercícios de 2014 a 2016, aplicando o modelo de ajuste de Barbosa, Barros, Niyama e Souza (2011). Impactos expressivos foram observados no ativo e passivo das empresas, redução da liquidez corrente, da composição do endividamento e do retorno sobre 0 ativo, bem como aumento do grau de endividamento, imobilização do patrimônio líquido e grau de alavancagem financeira, enquanto apenas o retorno sobre patrimônio líquido permaneceu inalterado.

Palavras-chave: Arrendamento Operacional. Arrendatária. Indicadores Econômico-Financeiros. IFRS 16. http://dx.doi.org/10.5380/rc\&c.v10i3.59455 


\title{
MAIN IMPACTS OF THE NEW INTERNATIONAL LEASES STANDARD ON THE ECONOMIC AND FINANCIAL RATIOS OF AIRLINES COMPANIES GOL AND LATAM
}

\begin{abstract}
The accounting rules for leasing have been the source of discussions because the operations in the operating mode do not consider these transactions in their balance sheet, affecting transparency of the information. With a new lease standard, IFRS 16, in principle, these operations will be included in the financial statements of all lessees. The objective of this study was to analyze the main effects of the new rule, when used a similar accounting treatment of financial lease to the operational classification, in the economic and financial ratios of the organizations GOL and LATAM, for the years 2014 to 2016, applying the Barbosa, Barros, Niyama and Souza's (2011) adjustment model. Significant impacts were observed in the assets and liabilities of the companies, reduction of current liquidity, composition of indebtedness and return on assets, as well as increased the degree of indebtedness, immobilization of shareholders' equity and degree of financial leverage, while only the return on equity remained unchanged.
\end{abstract}

Keywords: Operating Lease. Lessee. Economic and Financial Ratios. IFRS 16.

\section{Introdução}

Uma das formas alternativas de financiamento de ativos no qual as empresas podem recorrer é o arrendamento mercantil, definido pelo Comitê de Pronunciamentos Contábeis (CPC) (2010, p. 2), no Pronunciamento Técnico CPC 06, como "um acordo pelo qual o arrendador transmite ao arrendatário em troca de um pagamento ou série de pagamentos o direito de usar um ativo por um período de tempo acordado".

Essa transação apresenta duas classificações: a financeira e a operacional. Enquanto na primeira, o arrendatário realiza a contabilização do bem arrendado no ativo e das obrigações de pagamento no passivo, na modalidade operacional isso não ocorre e essas informações são divulgadas apenas em notas explicativas. Desse modo, em específico para organizações enquadradas nessa segunda situação, surgem questionamentos quanto à transparência dessas operações nas demonstrações contábeis, em especial no balanço patrimonial. Conforme estimativa feita pela Securities and Exchange Commission [SEC] (2005), cerca de 1,25 trilhões de dólares de compromissos referentes ao arrendamento operacional não foram computados no balanço de companhias abertas no mercado norte-americano.

Segundo Duke, Hsieh e Su (2009), já é de longa data que as empresas vêm se beneficiando destas particularidades da classificação operacional, não apenas dos saldos que ficam de fora das demonstrações, mas também do aumento no lucro e da melhora em índices econômico-financeiros.

Essas circunstâncias propiciaram toda uma discussão acerca da temática, que culminou, em janeiro de 2016, na publicação da nova norma, a International Financial Reporting Standard (IFRS) 16 - Leasing, emitida pelo International Accounting Standards Board (IASB). Ela é obrigatória a partir de 2019 e substitui a norma internacional vigente que trata dessas operações, a International Accounting Standards (IAS) 17.

A IFRS 16, dentre outras modificações, expõe a atribuição para as arrendatárias, em princípio, em todos os contratos de arrendamento, de registrarem um ativo referente ao direito de uso e um passivo relacionado aos pagamentos futuros. Assim, o presente estudo teve como foco as companhias que pertencem ao setor aéreo, por ser uma das áreas que mais concentram essas operações, de acordo com a International Financial Reporting Standard Foundation [IFRS Foundation] (2016a).

Neste sentido, foi tomado como base para a execução deste trabalho, o artigo dos autores Barbosa, Barros, Niyama e Souza (2011). Eles objetivaram observar os reflexos causados na estrutura patrimonial das 
organizações TAM e GOL, de 2007 a 2009, quando contabilizado o arrendamento operacional de modo equivalente à modalidade financeira. Para isso, efetuaram as devidas adaptações em seus respectivos balanços utilizando as informações sobre tais transações contidas nas notas explicativas.

No presente estudo foi aplicado esse mesmo modelo de ajuste em outro período de tempo com o fim de responder a seguinte questão: quais são os impactos da nova norma de arrendamento mercantil nos indicadores econômico-financeiros de companhias aéreas?

Por conseguinte, o objetivo geral desta pesquisa foi analisar os principais efeitos da IFRS 16, quando dado um tratamento contábil similar do arrendamento financeiro à classificação operacional, nos indicadores econômico-financeiros das empresas aéreas GOL e LATAM, para os períodos de 2014 a 2016.

A fim de alcançar esse objetivo maior, foi necessário desenvolver os objetivos específicos a seguir: explicar a evolução legal e normativa referente ao arrendamento mercantil e expor comparativamente as diferenças e similaridades entre as normas.

A relevância do tema se justifica uma vez que com a melhora na transparência da informação sobre 0 arrendamento, proporcionada pela IFRS 16, indicadores econômico-financeiros poderão ser afetados de maneira expressiva e a tomada de decisão do usuário da informação contábil poderá ser influenciada significativamente. Ademais, toda essa discussão se concentra em países estrangeiros. Logo, pode ser pertinente dar continuidade a um debate voltado para o mercado brasileiro.

Além disso, com relação à importância do setor aéreo para a economia brasileira, de acordo com os dados apurados pela Oxford Economics (2016), apesar de apenas 1,4\% do PIB do país prover desse tipo de transporte e do turismo proporcionado pela via aérea, 1,1 milhão de empregos diretos e indiretos foram gerados por este setor em 2014.

Portanto, conforme já exposto, esta pesquisa foi delimitada de modo a analisar duas organizações aéreas por um período de três anos.

\section{Referencial Teórico}

No Brasil, pela Lei 6.404 (1976) era entendido o seguinte: como a arrendatária não possui a propriedade do bem, em nenhuma das duas modalidades, nem na financeira e nem na operacional, era registrado 0 ativo em seu balanço. Todavia, com a Lei 11.638 (2007), passou a ser levada em conta a aplicação da essência sobre a forma no momento da classificação do arrendamento e, assim, por mais que a arrendatária não detivesse o título de propriedade do bem, poderia realizar a contabilização do ativo e do passivo, desde que os riscos e benefícios estivessem atrelados a ela, o que modificou a forma de reconhecimento do arrendamento mercantil financeiro (ludícibus, Martins, Gelbcke, \& Santos, 2010).

Contudo, 0 arrendamento operacional permaneceu de fora do balanço patrimonial da arrendatária, 0 que colaborou para o prosseguimento da discussão quanto à transparência das operações de arrendamento nas demonstrações contábeis, porém com foco na modalidade operacional.

Observa-se que já na década de 1990, o grupo G4+1, formado pelos órgãos normatizadores de contabilidade da Austrália, Canadá, Estados Unidos, Nova Zelândia e Reino Unido, junto ao antigo International Accounting Standards Committee (IASC), chegaram a participar desse debate sobre 0 arrendamento operacional.

Em 1996, foi publicado o chamado Accounting for Leases: A New Approach, que foi seguido por um segundo relatório especial publicado em 2000, o Leases: Implementation of a New Approach. Esses documentos vistos em conjunto apresentavam justamente uma abordagem de reconhecimento, por parte do arrendatário, do valor justo dos ativos e passivos do contrato de arrendamento. 
Segundo Lipe (2001), tais debates e conclusões aos quais o grupo chegava, apesar de não serem reconhecidas como Princípios Contábeis Geralmente Aceitos (GAAP), poderiam influenciar na criação de novas regras. Entretanto, em um relatório divulgado pela SEC (2005), foi evidenciado que um projeto de mudança da contabilidade aplicada ao arrendamento poderia levar tempo para ser discutida e aprovada, tanto por se tratar de um assunto de grande importância, como pela possibilidade de empresas manifestarem reações negativas à alteração, uma vez que a modalidade operacional pode ser uma atrativa alternativa ao financiamento de ativo, cuja obrigação total de liquidar a dívida não seria considerada no balanço.

Em 2010 foi emitido o Exposure Draft - Leases, e logo em 2013 foi feita uma revisão. Esse documento é uma minuta de discussão, de maneira geral, sobre a proposta de adoção do modelo right of use (direito de uso) para todos os contratos de arrendamento, no qual contempla o reconhecimento, por parte dos arrendatários, dos ativos e passivos referentes a essa operação.

Enfim, em janeiro de 2016 foi publicada a nova norma sobre arrendamento mercantil, emitida pelo IASB, a IFRS 16 que substituirá a IAS 17. A partir de $1^{\circ}$ de janeiro de 2019 tornou-se obrigatória a adoção das novas regras, porém caso a companhia queira aplicá-la com antecedência, também precisará aderir à norma IFRS 15, que trata sobre receita de contratos com clientes.

O fato da modalidade operacional não ser registrada nas demonstrações das arrendatárias, é objeto de uma das mais fortes críticas ao IAS 17 (EYGM Limited, 2016). Além disso, Paul Sutcliffe, sócio de IFRS Services da Ernst \& Young, chegou a afirmar que "com muito planejamento, algumas empresas davam um jeito de parecer que a operação era quase sempre operacional e não financeira. Em vez de registrar um ativo e um passivo, não se registrava nada" (EYGM Limited, 2016, p. 10).

O Capital Markets Advisory Committee, por sua vez, um grupo de investidores que prestam recomendações ao IASB, também expressou a sua opinião quanto à divulgação das informações dos arrendamentos operacionais apenas nas notas explicativas das arrendatárias: "não seria útil para a maioria dos investidores que necessitam de demonstrações contábeis que forneçam informações precisas desde o início" (IFRS Foundation, 2016a, p. 22, tradução nossa).

Diante deste cenário, Hans Hoogervorst, presidente do IASB, declarou que "os novos requisitos contábeis trazem a contabilidade do arrendamento para o século 21" (IFRS Foundation, 2016b, p. 1, tradução nossa).

\subsection{Procedimentos contábeis correntes do Arrendamento Mercantil}

No CPC 06, o arrendamento mercantil é definido como "um acordo pelo qual o arrendador transmite ao arrendatário em troca de um pagamento ou série de pagamentos o direito de usar um ativo por um período de tempo acordado" (CPC, 2010, p. 2). A norma evidencia as seguintes modalidades de arrendamento: 0 financeiro, similar a uma compra financiada, e o operacional, similar a um aluguel. Tal classificação "baseia-se na extensão em que os riscos e benefícios inerentes à propriedade de ativo arrendado permanecem no arrendador ou no arrendatário" (CPC, 2010, p. 5).

Com relação aos riscos, esses "incluem as possibilidades de perdas devidas à capacidade ociosa ou obsolescência tecnológica e de variações no retorno em função de alterações nas condições econômicas", conforme dispõe o CPC (2010, p. 5), que relata que os benefícios, por sua vez, "podem ser representados pela expectativa de operações lucrativas durante a vida econômica do ativo e de ganhos derivados de aumentos de valor ou de realização do valor residual".

Os arrendatários em um arrendamento mercantil financeiro devem, no início do contrato, reconhecer em seu balanço patrimonial, os ativos e passivos referentes a essa operação pelo valor justo do bem arrendado ou pelo valor presente dos pagamentos mínimos da transação, dos dois o menor (CPC, 2010; ludícibus et al., 2010). 
Os juros a transcorrer será uma conta redutora dessas obrigações e o registro da despesa financeira, em cada período, deverá obedecer ao regime de competência (ludícibus et al., 2010), assim como a depreciação do bem arrendado. Se houver a certeza da transferência do título de propriedade para 0 arrendatário ao final do contrato, será levada em consideração a vida útil do ativo, porém se não houver essa certeza, será levado em consideração o prazo do arrendamento ou a vida útil do bem, dos dois o menor (CPC, 2010).

Já os arrendatários em um arrendamento mercantil operacional, têm que registrar os pagamentos dessa operação como despesa em base linear no decurso do contrato de arrendamento, salvo se outro método se fundamentar de modo significativo (CPC, 2010). Essa despesa irá gerar uma contrapartida a uma obrigação ou a uma disponibilidade, o que indica que não será apresentado no balanço 0 ativo arrendado e nem 0 total da dívida no início do prazo. Esse último poderá vir a ser reconhecido no transcorrer das parcelas (ludícibus et al., 2010).

$\mathrm{O}$ arrendador em um arrendamento mercantil financeiro registrará no balanço um ativo de contas a receber pelo valor do investimento líquido no arrendamento. Os pagamentos realizados pelo arrendatário serão representados para o arrendador como uma amortização do valor a receber e como sendo receita financeira. Essa última será reconhecida no decorrer do prazo do contrato em base sistemática e racional, ou seja, levará em conta o retorno constante a cada período sobre o investimento líquido (CPC, 2010; ludícibus et al., 2010).

Enquanto que em um arrendamento mercantil operacional, vale lembrar que 0 ativo é propriedade do arrendador, assim como na modalidade financeira, porém os riscos e benefícios permanecem com ele. Então, diferente da classificação financeira, o ativo arrendado permanece em seu balanço patrimonial. Assim, 0 arrendador deverá reconhecer a receita dos pagamentos do arrendatário, bem como a depreciação do bem arrendado (ludícibus et al., 2010).

\subsection{Procedimentos contábeis do Arrendamento Mercantil segundo a IFRS 16}

De acordo com a IFRS Foundation (2016a, p. 11, tradução nossa), a nova norma "mantém a definição de arrendamento do IAS 17, mas altera a orientação que explica como aplicá-lo. As mudanças referem-se principalmente ao conceito de controle".

A IFRS 16 é empregada somente em arrendamentos ou em componentes de arrendamento de um contrato. Dessa forma, alguns elementos que possivelmente até então eram contabilizados em concordância com os requisitos do IAS 17, irão deixar de ser considerados pelas novas regras, como os componentes de serviço que constantemente estão agrupados ao arrendamento em um único contrato (IFRS Foundation, 2016a).

Conforme a KPMG International Standards Group (2016), ao aplicar o IAS 17, acaba sendo necessário que analistas e investidores ajustem as demonstrações contábeis dos arrendatários de maneira a contemplar 0 arrendamento mercantil operacional. Por outro lado, ao adotar a IFRS 16, essas adaptações serão dispensáveis, tendo em vista que tais transações já serão consideradas nas demonstrações, havendo apenas um modelo contábil para o arrendatário, não mais a divisão em duas modalidades.

Os arrendatários que estiverem diante de arrendamentos de curto prazo e, aqueles em que 0 ativo arrendado seja de baixo valor, como o arrendamento de um computador (IFRS Foundation, 2016a), estarão isentos de obedecer a essa nova regra de contabilização.

0 passivo de arrendamento será inicialmente mensurado pelo valor presente das parcelas desta transação, com base em uma taxa de desconto (Deloitte Touche Tohmatsu Limited, 2016a).

O prazo da operação corresponderá ao seu período não cancelável, que poderá ser somado aos "períodos cobertos por uma opção para estender o arrendamento, se o arrendatário estiver razoavelmente certo 
em exercer essa opção", bem como "aos períodos cobertos por uma opção para rescindir o arrendamento, se o arrendatário estiver razoavelmente certo em não exercer essa opção" (Deloitte Touche Tohmatsu Limited, 2016b, p. 31, tradução nossa).

De maneira semelhante à norma vigente, serão englobados ao montante das obrigações de tais transações, os pagamentos variáveis do arrendamento que estão vinculados a um índice ou a uma taxa (como, por exemplo, a taxa de inflação) e os pagamentos fixos em substância, ou seja, os que "são estruturados como pagamentos variáveis do arrendamento, mas que em substância são inevitáveis", como os "pagamentos que têm de ser feitos somente se ocorrer um evento que não tenha nenhuma possibilidade real de não ocorrer" (KPMG International Standards Group, 2016, p. 24).

Com relação aos outros pagamentos variáveis (por exemplo, os que estão diretamente relacionados às receitas auferidas pelo uso do ativo arrendado), esses não serão acrescentados na medição inicial do passivo. As despesas desses pagamentos são registradas no período em que as circunstâncias que os originam ocorrerem, e, quando determinado, a contrapartida desses lançamentos serão o passivo de arrendamento. Diante disso, a entidade não precisará estimar, na data inicial, todos os pagamentos variáveis (KPMG International Standards Group, 2016).

A companhia de auditoria e consultoria ressaltou que também serão integrados ao montante inicial do passivo: o valor a pagar esperado como garantia de valor residual, o preço de compra caso 0 arrendatário esteja razoavelmente certo disso, bem como os valores a pagar pela rescisão do contrato no caso do prazo da operação indicar um rompimento adiantado.

No que diz respeito à quantia referente à garantia de valor residual, com base na IFRS 16 será comum ela ser inferior caso fossem seguidas as regras do IAS 17. Isso porque, enquanto a nova norma orienta que seja computado um valor a pagar esperado, pela prática corrente é calculado um valor máximo (KPMG International Standards Group, 2016).

Apesar de na IFRS 16 o ativo de direito de uso não ser confirmado como sendo um imobilizado ou intangível, a sua mensuração inicial, de modo genérico, coadunará com a desses ativos não financeiros. Ou seja, a princípio serão computados pelos seus respectivos custos. Dependendo da maneira como demais instituições contábeis e órgãos regulatórios irão defini-lo, grandes repercussões poderão ser geradas, por exemplo, no que diz respeito às questões fiscais dos arrendamentos (KPMG International Standards Group, 2016).

No tocante à mensuração subsequente do passivo de arrendamento, deverá ser empregado o método da taxa de juros efetiva para calcular o custo amortizado e a despesa de juros do período. Mas, cabe mencionar que há a possibilidade dessa obrigação precisar ser mensurada novamente. Nesse processo, serão utilizados os novos valores dos pagamentos de arrendamento e a mesma taxa de desconto ou uma nova taxa, a depender da situação (KPMG International Standards Group, 2016).

A mensuração subsequente do ativo de direito de uso normalmente se dará pelo valor inicial contabilizado, o preço-custo, subtraído da depreciação acumulada e da perda por impairment, se houver. Todavia, o direito de uso, para o qual o bem arrendado seja um imobilizado, também poderá ser mensurado novamente, de modo a acompanhar a reavaliação do passivo de arrendamento, a não ser que "o valor contábil do ativo de direito de uso já esteja reduzido a zero ou a alteração no passivo de arrendamento diga respeito a um pagamento variável de arrendamento que não dependa de um índice ou uma taxa" (KPMG International Standards Group, 2016, p. 32). Nesses cenários citados, o ajuste no passivo não provocará ajuste no ativo, mas sim na demonstração do resultado do exercício.

Como dito anteriormente, a IFRS 16 não afirma o direito de uso como sendo um intangível ou tangível, contudo, ainda de acordo com a KPMG International Standards Group (2016), as condições a serem adotadas para a sua depreciação seguirão o escopo do IAS 16 (o equivalente ao CPC 27), que trata do ativo imobilizado. 
Usualmente, a depreciação ocorrerá em uma base linear, enquanto que a despesa de juros decrescerá ao longo do prazo de arrendamento, tendo em vista que isso também ocorrerá com o passivo dessa transação no decurso desse tempo. Dessa forma, percebe-se que a despesa total de arrendamento será maior na data inicial.

Ressalta-se que até a entrada em vigor dessa norma, essa era uma peculiaridade apenas da modalidade de arrendamento financeira (KPMG International Standards Group, 2016).

No que diz respeito à contabilidade do arrendador, a IFRS 16, em sua maior parte, é igual ao IAS 17. A classificação do arrendamento em duas modalidades permanece, tal como os requisitos para determiná-las. Diante deste quadro, o modelo contábil duplo para o arrendador também será mantido. No entanto, de acordo com a KPMG International Standards Group (2016, p. 40), isso "traz inconsistência diante do novo modelo de contabilização do arrendatário".

A companhia de auditoria e consultoria explicou que em uma situação que para 0 arrendador 0 arrendamento seja entendido como operacional, o ativo negociado permanecerá em seu balanço e não haverá o registro de contas a receber relativo aos pagamentos do arrendatário, ao mesmo tempo em que esse último, por sua vez, reconhecerá o ativo do direito de uso e as obrigações de pagamento, diante de seu modelo contábil único. Além disso, outro ponto mencionado que evidencia certa incoerência é o fato de que os arrendatários reavaliarão suas considerações iniciais sobre a possibilidade de compra do bem e o prazo do arrendamento, mas os arrendadores não.

A nova norma introduz algumas modificações para o arrendador, por exemplo, a definição de arrendamento já explicada, bem como um maior nível de exigência de divulgação de informações. Todavia, ainda assim, menos extenso em comparação ao que passa a ser demandado dos arrendatários (KPMG International Standards Group, 2016).

\subsection{Efeitos esperados da mudança para a IFRS 16}

O IASB resolveu analisar empresas listadas de todas as partes do mundo que aplicam as IFRS ou US GAAP (Princípios Contábeis Geralmente Aceitos nos Estados Unidos), conforme consta no material instrutivo da IFRS Foundation (2016a). De um total de aproximadamente 30.000 companhias pesquisadas, foi verificado que mais de 14.000 recorrem à modalidade operacional, totalizando cerca de 2,86 trilhões de dólares de pagamentos futuros de arrendamentos que estão fora do balanço, descontando o valor presente passam a ser 2,18 trilhões de dólares.

Então, espera-se que essas mais de 14.000 organizações sejam afetadas pela alteração da norma. Porém, alguns setores da indústria serão mais do que outros, a depender do peso de seus arrendamentos operacionais.

Assim, observou-se que 1,66 trilhões de dólares, relativo aos pagamentos fora do balanço, do total de 2,18 trilhões de dólares (ou seja, 76\% desse montante) está concentrado em uma amostra de 1.022 empresas. A partir disso, ao examinar cada setor em que essas companhias fazem parte, ficou constatado que 0 setor aéreo pode ser um dos mais impactados ao empregar a IFRS 16, tendo em vista que o valor atual dos pagamentos futuros de arrendamento operacional representa $22,7 \%$ do ativo total (IFRS Foundation, 2016a).

É importante ressaltar que incluir os arrendamentos operacionais nas demonstrações resultará, por exemplo, em uma elevação do total de ativos, do endividamento, da alavancagem financeira, bem como do lucro antes de juros, impostos, depreciação e amortização (EBITDA) por conta da fragmentação das despesas de arrendamento em despesas operacionais e financeiras. 
Por outro lado, o giro do ativo tenderá a diminuir. Em razão desse impacto nos indicadores de desempenho, as empresas podem ter dificuldade no cumprimento de determinadas cláusulas contratuais (covenants). (KPMG International Standards Group, 2016).

Dessa forma, dependendo da intensidade com que as companhias optem pelo arredamento operacional como financiamento de ativos, ao considerá-lo nos relatórios contábeis seus indicadores econômico-financeiros também poderão acabar sendo atingidos de forma expressiva.

No entanto, a expectativa da IFRS Foundation (2016a), é que com a IFRS 16, a qualidade das informações contidas nas demonstrações contábeis de empresas que recorrem ao arrendamento operacional a um nível relevante seja aprimorada. Argumenta-se que ao registrar, em tese, todos os arrendamentos, isso permitirá uma melhor representação da posição econômico-financeira da companhia, maior transparência das informações sobre tais transações e sobre o capital investido. Com isso, serão gerados benefícios para investidores e analistas no processo de tomada de decisão, tendo em vista que poderão analisar melhor 0 desempenho das organizações arrendatárias e sem a necessidade de ajustar as demonstrações de forma a abranger os saldos da modalidade operacional que, com a aplicação do IAS 17 não são contabilizados.

Ressalta-se que os ajustes mencionados anteriormente, por vezes são superavaliados e são utilizadas as mais diferentes técnicas. Por conseguinte, "espera-se que a posição financeira reportada da empresa seja mais precisa aplicando a IFRS 16 do que a posição financeira ajustada pelos investidores e analistas que aplicam a IAS 17" (IFRS Foundation, 2016a, p. 26, tradução nossa).

Outro ponto levantado pela IFRS Foundation (2016a) é que perante as regras vigentes, se não forem realizados os devidos ajustes, a comparação entre organizações com arrendamentos operacionais pode ficar prejudicada. Pode acontecer, por exemplo, de duas empresas que recorrem a essas transações a níveis diferentes, ao seguirem os requisitos do IAS 17, uma aparente estar com um melhor desempenho econômicofinanceiro do que a outra, ou então pareçam estar em situações semelhantes. Porém, isso pode passar a não ser mais verdade ao obedecer às orientações da IFRS 16 e, assim, considerar os montantes que antes ficaram de fora.

Sobre a implantação da IFRS 16, Gary Kabureck, membro do IASB, chamou a atenção das organizações para fazerem isso o quanto antes. Pelo que foi apurado, as empresas que já anteciparam a implementação se depararam com fases iniciais requerendo bastante tempo (Lloyd, Kabureck, Scott, \& Cooper, 2017).

\subsection{Contribuições e pesquisas recentes}

Antes mesmo da criação da nova norma, diversos autores, em sua maioria estrangeiros, desenvolveram artigos com essa temática, buscando, entre outros pontos, identificar quais seriam as principais mudanças necessárias para uma nova contabilização do arrendamento mercantil, assim como avaliar se tais modificações gerariam efeitos relevantes sobre os índices econômico-financeiros de empresas arrendatárias, de determinado(s) setor (es), para determinado(s) período(s).

Bennett e Bradbury (2003), por exemplo, analisaram os reflexos que podem ser causados ao considerar o arrendamento operacional nas demonstrações contábeis de 38 organizações relacionadas na Bolsa de Valores da Nova Zelândia, para o ano de 1995. Eles observaram na amostra efeitos negativos significativos no total de passivo, no qual teve um aumento médio de 22,9\%; no índice de liquidez corrente, com uma redução média de 14,41\%; no endividamento, que cresceu em média 10,66\%; e no retorno sobre 0 ativo, que diminuiu em média $8,73 \%$. Os autores aplicaram o método de capitalização construtiva, um modelo de Imhoff, Lipe e Wright $(1991,1993,1995,1997)$, que simula o impacto da capitalização do arrendamento operacional no ativo, no passivo, no patrimônio líquido e na demonstração do resultado do exercício, desde o início do contrato.

Batista e Formigoni (2013), por sua vez, com base nas alterações contidas no Exposure Draft/2010, examinaram, para o ano de 2010, 32 companhias abertas brasileiras dos segmentos industriais e de serviços.

RC\&C - Revista Contabilidade e Controladoria, Curitiba, v. 10, n. 3, p. 86-106, set./dez. 2018. 
Os autores alegaram que as taxas firmadas no contrato de arrendamento mercantil não foram comunicadas nas notas explicativas, o que os levou a adotarem o limite máximo legal permitido, uma taxa de juros uniforme de $12 \%$ ao ano. Essa foi a taxa de desconto usada para apurar o valor presente das prestações de arrendamento operacional, e, assim, adicionar esse montante às demonstrações contábeis. Como resultado desses ajustes, foram identificadas as seguintes repercussões no cálculo dos indicadores econômicofinanceiros: o índice de liquidez corrente diminuiu em 23 empresas, sendo que em 15 delas a decaída foi maior ou igual a 10\%. À medida que o endividamento aumentou em 17 organizações, nos quais em 12 esse incremento foi de até 5\%; o grau de endividamento cresceu em 25 companhias, tendo em 13 delas uma expansão maior que 10\%. Quanto ao retorno sobre o ativo, esse caiu em até $5 \%$ em 8 empresas, enquanto que o retorno sobre o patrimônio líquido permaneceu inalterado para todas as organizações da amostra.

Em geral, esses impactos também foram notados pelos autores Fitó, Moya e Orgaz (2013) ao analisarem, para o período de 2008 a 2010, 52 companhias espanholas. Como base para a pesquisa, eles utilizaram o modelo de Imhoff et al. $(1991,1997)$ de capitalização construtiva para ajustar as quantias de arrendamento que estavam fora das demonstrações. Foi observado que os indicadores financeiros seriam estatisticamente impactados de maneira significativa, o que poderia gerar reflexos na estrutura de capital das empresas, em sua posição no mercado e na forma como investidores as enxergam. A liquidez corrente, por exemplo, decresceu em média $5,64 \%$, já o endividamento expandiu em média $3,45 \%$. Além disso, o indicador de desempenho econômico das organizações também seria afetado, com uma queda em média de 16,67\% para o retorno sobre 0 ativo.

Já no contexto brasileiro, Martins, Silva Filho, Girão e Niyama (2013) analisaram os índices de estrutura de 12 companhias do subsetor de transporte relacionadas na Bolsa de Valores, Mercadorias e Futuros de São Paulo, referentes ao ano de 2011. Eles levaram em consideração as alterações sugeridas no Exposure Draft/2010 e aplicaram uma metodologia de simulação do que foi proposto nesse documento, em conjunto com o teste $t$ de Student a fim de detectar se ocorreram grandes modificações nos índices. O resultado obtido revelou um saldo fora do balanço superior a 3,5 bilhões de reais advindos do arrendamento operacional, sendo mais de $70 \%$ pertencentes às empresas aéreas TAM e GOL. Ao empregar as informações contábeis sem a simulação do que foi proposto no Exposure Draft e com a simulação, observou-se também uma diferença relevante na média do grau de endividamento e da imobilização do patrimônio líquido, com um aumento de $8,22 \%$ e $8,21 \%$, respectivamente.

Machado, Machado, e Martins (2013), ao analisarem 43 companhias brasileiras e suas respectivas notas explicativas perceberam fora do balanço, tanto para o período de 2010 como o de 2011, que em média, mais de 400 milhões de reais pertencentes às obrigações de arrendamento operacional, descontadas a valor presente.

Joshi e Wong (2015), do mesmo modo como foi constatado pelos autores anteriores, uma vez integrado o montante dessas transações nas demonstrações, os índices de endividamento e grau de endividamento também seriam impactados de maneira relevante, com uma elevação de 10,11\% e 31,69\%, respectivamente, ao passo que o retorno sobre o ativo e o retorno sobre o patrimônio líquido também seriam afetados, entretanto, com uma queda de 15,35\% e 1,23\%, respectivamente. Para esse estudo foi aplicado o modelo de Imhoff et al. (1991) de capitalização construtiva, e foram examinadas, para o ano de 2010, 107 empresas de diversos setores, como o de biotecnologia, de energia e da área da saúde, relacionadas na Bolsa de Valores Australiana.

Díaz (2016) relatou em seu artigo os efeitos mais significativos das novas regras, dentre eles: efeitos expressivos no EBITDA e reflexos no endividamento da arrendatária, tal como no grau de endividamento, o que já foi sustentado em outros trabalhos, entretanto, tendo como base o Exposure Draft. $O$ autor sugeriu ainda que as organizações formassem uma equipe para elaborarem um plano de adoção da nova norma, atentando-se também aos custos de transição.

Portanto, ao incluir o arrendamento operacional nas demonstrações contábeis das arrendatárias, note que há um consenso entre os resultados das pesquisas quanto ao aumento do endividamento e do grau de endividamento, bem como quanto à redução do índice de liquidez corrente e do retorno sobre 0 ativo. Por outro 
lado, houve divergência quanto ao retorno sobre o patrimônio líquido enquanto que para Batista e Formigoni (2013) esse indicador não sofreu alteração, no trabalho de Joshi e Wong (2015) houve uma queda.

\section{Procedimentos Metodológicos}

Observados os agrupamentos de tipologias de pesquisa categorizados por Beuren (2013), este trabalho pode ser classificado quanto aos objetivos, como sendo descritivo; quanto aos procedimentos, como um estudo de caso; e quanto à abordagem do problema, como qualitativo.

Conforme Gil (2008, p. 28), as pesquisas descritivas "têm como objetivo primordial a descrição das características de determinada população ou fenômeno ou o estabelecimento de relações entre variáveis". Nesse sentido, no presente estudo foram explicadas as principais mudanças trazidas pela nova norma de arrendamento mercantil, a fim de entender os efeitos que isso poderia causar nos indicadores econômicofinanceiros das empresas que optam por essa alternativa de financiamento de ativo.

Este trabalho focou em duas organizações do setor aéreo: as empresas GOL e LATAM, e também pode ser considerado como sendo um estudo de caso, pois "é caracterizado pelo estudo profundo e exaustivo de um ou de poucos objetos, de maneira a permitir o seu conhecimento amplo e detalhado" (Gil, 2008, p. 57). Segundo Beuren (2013, p. 84), esse tipo de trabalho "é preferido pelos pesquisadores que desejam aprofundar seus conhecimentos a respeito de determinado caso específico".

Assim, mediante uma metodologia qualitativa, foram analisados quais os impactos que a IFRS 16 poderia causar nos indicadores econômico-financeiros das companhias abertas, GOL e LATAM, nos períodos de 2014 a 2016. A depender dessas repercussões geradas sobre essas variáveis, havendo efeitos expressivos, o processo de tomada de decisão dos usuários da informação contábil poderia ser influenciado significativamente.

De acordo com Richardson (2012, p. 80), pesquisas desse perfil, com uma abordagem qualitativa, "podem descrever a complexidade de determinado problema, analisar a interação de certas variáveis, compreender e classificar processos dinâmicos vividos por grupos sociais".

Os dados das duas organizações foram coletados em outubro de 2017 , no portal de relação com os investidores. A base para este estudo está respaldada no artigo de Barbosa et al. (2011), no qual buscou-se averiguar os efeitos que a contabilização do arrendamento operacional realizado de modo equivalente à classificação financeira, geraria sobre a estrutura patrimonial das companhias TAM e GOL, para os períodos de 2007 a 2009. Os autores justificaram a escolha dessas empresas, por possuírem ampla participação no mercado aéreo brasileiro à época, próxima a $90 \%$. Já os períodos de tempo foram justificados pela convergência às normas internacionais a partir de 2007.

Para efetuarem a avaliação de cada organização, foi necessário, primeiramente, a realização de ajustes para os três anos de análise. Os dados sobre os pagamentos dos arrendamentos operacionais foram obtidos nas próprias notas explicativas, o que foi assinalado pelos estudiosos como uma limitação, uma vez que caso tivessem acesso a todas as informações a respeito dessas transações, as adaptações não teriam sido exatamente as mesmas. A atenção, então, foi voltada em específico ao balanço patrimonial, por compreenderem que os efeitos diretos dos ajustes se dariam sobre esse relatório contábil, enquanto que a demonstração do resultado do exercício, por exemplo, seria impactada de maneira indireta.

Neste trabalho foi aplicado o modelo de ajuste de Barbosa et al. (2011), que consiste nos seguintes pontos:

[1] Na primeira etapa, foram retirados das notas explicativas das arrendatárias os montantes relativos ao arrendamento operacional e foram extraídos do balanço patrimonial os valores do ativo e passivo, tanto do circulante como do não circulante, bem como do patrimônio líquido. 
[2] Na segunda etapa, por sua vez, foram adicionados ao passivo circulante os valores dos pagamentos futuros dos arrendamentos operacionais de curto prazo.

[3] Já na terceira, foram acrescentadas ao passivo não circulante as quantias de longo prazo referentes a essas transações.

[4] Enquanto que na quarta etapa, foi somado ao ativo não circulante o total dos pagamentos futuros dessas operações.

Todos esses passos foram realizados para cada período da pesquisa, de 2014 a 2016.

[5] Posto isso, na quinta e última etapa, assim como foi feito no artigo base, foram calculados, antes e após os ajustes dos saldos do arrendamento operacional, para cada ano e para cada empresa, os indicadores econômico-financeiros explicados no quadro a seguir. Isso foi fundamental para examinar a diferença de uma situação para a outra.

Conforme já discutido na seção de Contribuições e Pesquisas Recentes, todos os autores em seus trabalhos chegaram à conclusão de que, ao levar em conta o montante do arrendamento operacional nas demonstrações contábeis das arrendatárias, haveria um crescimento do grau de endividamento, bem como uma diminuição da liquidez corrente e do retorno sobre 0 ativo. Entretanto, houve discordância quanto ao retorno sobre o patrimônio líquido, no qual segundo Batista e Formigoni (2013) não sofreria mudança, mas para Joshi e Wong (2015) haveria uma redução.

É importante frisar que tanto a GOL como a LATAM não aplicaram antecipadamente a IFRS 16. Por isso, a necessidade de ter que buscar os dados sobre os arrendamentos operacionais nas notas explicativas e executar os ajustes no balanço patrimonial. No entanto, isso não representa todas as adequações que deveriam ser feitas nas demonstrações, uma vez que as informações encontradas se resumem aos valores dos pagamentos futuros dessas operações, desse modo, não foram incluídos os devidos lançamentos das despesas de juros e de depreciação do bem.

Além disso, também existem outras limitações, como o possível viés de avaliação no julgamento feito sob a ótica do próprio avaliador; assim como o reduzido espaço de tempo de análise, por se tratar de três anos; e o fato de não ser possível generalizar para todas as empresas, os impactos que a nova norma causou nas organizações que foram observadas, inclusive, porque nem todos os setores recorrem ao arrendamento operacional na mesma magnitude que companhias aéreas.

\section{Apresentação e Análise dos Resultados}

O setor aéreo será um dos mais afetados pela alteração da norma, pois as arrendatárias que fazem parte desse ramo recorrem a um alto nível de arrendamento operacional. Com isso, nesta seção foram abordados os resultados dos indicadores econômico-financeiros das empresas aéreas GOL e LATAM, antes e após incluírem os montantes relativos ao arrendamento operacional no balanço patrimonial de cada uma delas. Também foi feito um comparativo com o artigo base de Barbosa et al. (2011).

Segundo a Agência Nacional de Aviação Civil [ANAC] (2017), a companhia GOL, listada na Bolsa de Valores, Mercadorias e Futuros de São Paulo, vem exercendo liderança no mercado doméstico de passageiros desde maio de 2016. Essa empresa, em outubro de 2017, teve uma participação de 35,9\% na demanda de voos domésticos, a qual é medida em passageiros-quilômetros pagos transportados.

Mas vale comentar que essa organização vem salientando certos problemas em seu resultado do exercício. Em 2015, ela teve um prejuízo líquido de aproximadamente $\mathrm{R} \$ 4,3$ bilhões. Já em 2016, embora tenha tido lucro, seu patrimônio líquido continuou com um elevado valor negativo. Em 2017, houve certa oscilação, tendo lucro no primeiro e terceiro trimestres, porém prejuízo no segundo. 
Com relação à adoção das novas práticas contábeis de arrendamento mercantil, isso também pode exigir da GOL certa atenção, por conta do impacto em seus indicadores econômico-financeiros.

Para analisar os efeitos que poderão ser gerados, foi preciso primeiro acrescentar as quantias do arrendamento operacional em suas demonstrações contábeis.

Assim, na Tabela 1, foi evidenciado o balanço patrimonial da GOL, antes e após esses ajustes, para os períodos de 2014 a 2016.

Tabela 1: Balanço Patrimonial da GOL, com e sem ajustes, dos anos de 2014, 2015 e 2016 (em milhares de reais)

\begin{tabular}{lcccccc}
\hline \multicolumn{1}{c}{ GOL } & \multicolumn{2}{c}{2016} & \multicolumn{2}{c}{2015} & 2014 \\
\hline Grupo de Contas & Sem ajuste & Com ajuste & Sem ajuste & Com ajuste & Sem ajuste & Com ajuste \\
\hline $\begin{array}{l}\text { Ativo Circulante } \\
\begin{array}{l}\text { Ativo Não } \\
\text { Circulante }\end{array}\end{array}$ & 2.080 .714 & 2.080 .714 & 2.461 .566 & 2.461 .566 & 2.986 .198 & 2.986 .198 \\
\hline Ativo Total & 6.323 .641 & 12.570 .366 & 7.906 .831 & 15.655 .863 & 6.990 .449 & 11.785 .259 \\
\hline $\begin{array}{l}\text { Passivo } \\
\text { Circulante }\end{array}$ & 4.404 .355 & 14.651 .080 & 10.368 .397 & 18.117 .429 & 9.976 .647 & 14.771 .457 \\
$\begin{array}{l}\text { Passivo Não } \\
\text { Circulante }\end{array}$ & 6.912 .364 & 12.301 .342 & 9.148 .829 & 15.627 .577 & 6.096 .975 & 10.106 .733 \\
$\begin{array}{l}\text { Patrimônio } \\
\text { Líquido }\end{array}$ & -3.356 .751 & -3.356 .751 & -4.322 .440 & -4.322 .440 & -332.974 & -332.974 \\
\hline Passivo Total & 8.404 .355 & 14.651 .080 & 10.368 .397 & 18.117 .429 & 9.976 .647 & 14.771 .457 \\
\hline
\end{tabular}

Fonte: Elaborada pelos autores.

Ao integrar o ativo de direito de uso no balanço patrimonial, o ativo da companhia aumentou em 48\%, $75 \%$ e $74 \%$ nos períodos de 2014, 2015 e 2016, respectivamente, enquanto que no estudo de Barbosa et al. (2011), o crescimento do ativo da GOL foi de 44\%, 46\% e 29\% para os anos de 2007, 2008 e 2009, respectivamente.

Quando incorporadas as obrigações de pagamento do arrendamento operacional no passivo exigível, esse último ampliou em 47\% no exercício de 2014, e 53\% tanto em 2015 como em 2016. Na pesquisa de Barbosa et al. (2011), esse mesmo grupo de contas expandiu em 64\%, 54\% e 41\% em 2007, 2008 e 2009, respectivamente.

Comparando o primeiro ano de análise deste trabalho com o do artigo tomado como base, e fazendo 0 mesmo para o segundo e terceiro períodos, note que no presente estudo o passivo exigível denotou menor acréscimo, com exceção do último exercício, ao passo que o ativo total revelou maior crescimento, com destaque para o segundo e terceiro anos. Em 2015 e 2016, chegou a subir 29\% e 45\% a mais do que em 2008 e 2009, nessa ordem.

$\mathrm{Na}$ Tabela 2 foram exibidos os indicadores econômico-financeiros da GOL, antes e após de adicionar os saldos do arrendamento operacional, para que se possa examinar os efeitos da variação. Os índices calculados foram os mesmos utilizados por Barbosa et al. (2011). 
Principais impactos da Nova Norma Internacional de Arrendamento Mercantil sobre os indicadores econômico-financeiros das empresas aéreas GOL e LATAM.

Tabela 2: Indicadores calculados, com e sem ajustes, para a GOL

\begin{tabular}{|c|c|c|c|c|c|c|}
\hline GOL & & & & & & \\
\hline Indicadores & Sem ajuste & Com ajuste & Sem ajuste & Com ajuste & Sem ajuste & Com ajuste \\
\hline Liquidez Corrente & 0,429 & 0,365 & 0,444 & 0,361 & 0,709 & 0,598 \\
\hline Grau de Endividamento & $-3,504$ & $-5,365$ & $-3,399$ & $-5,191$ & $-30,962$ & $-45,362$ \\
\hline $\begin{array}{l}\text { Composição do } \\
\text { Endividamento }\end{array}$ & 0,412 & 0,317 & 0,377 & 0,304 & 0,409 & 0,331 \\
\hline $\begin{array}{l}\text { Imobilização do } \\
\text { Patrimônio Líquido }\end{array}$ & $-1,425$ & $-3,286$ & $-1,386$ & $-3,178$ & $-15,991$ & $-30,391$ \\
\hline Retorno sobre o Ativo & 0,074 & 0,043 & $-0,018$ & $-0,011$ & 0,049 & 0,034 \\
\hline $\begin{array}{l}\text { Retorno sobre o } \\
\text { Patrimônio Líquido }\end{array}$ & $-0,287$ & $-0,287$ & 1,844 & 1,844 & $-2,523$ & $-2,523$ \\
\hline $\begin{array}{l}\text { Grau de Alavancagem } \\
\text { Financeira }\end{array}$ & $-3,869$ & $-6,753$ & $-102,045$ & $-164,961$ & $-51,512$ & $-73,722$ \\
\hline
\end{tabular}

Fonte: Elaborada pelos autores.

Constata-se que nos três anos, ao adaptar o balanço patrimonial, a liquidez corrente diminuiu. Isso ocorreu, pois à medida que 0 ativo circulante não foi afetado pelos ajustes, no passivo circulante foi acrescido o montante da obrigação de curto prazo do arrendamento operacional. Dessa forma, a composição do endividamento também reduziu em todos os exercícios, uma vez que o aumento do capital de terceiros foi maior do que o do passivo circulante.

No que diz respeito ao retorno sobre o ativo, em 2014 e 2016 houve um decréscimo pelo fato da contabilização do direito de uso do bem ter elevado o ativo médio, enquanto que o lucro operacional não foi impactado pelos ajustes. Cabe mencionar que quando esses grupos de contas possuem valores absolutos, esse indicador apresentaria essa tendência de mudança, porém quando negativo, como no caso de haver prejuízo operacional, o retorno sobre o ativo teria um comportamento contrário. Por isso que em 2015, após os ajustes, esse índice ampliou.

Em razão de dificuldades que a GOL está passando, não há sentido na interpretação dos demais indicadores (grau de endividamento, imobilização do patrimônio líquido, retorno sobre o patrimônio líquido e grau de alavancagem financeira). Isso, porque a empresa obteve passivo a descoberto nos três anos de análise. Além disso, ela encerrou 2014 e 2015 com prejuízo líquido, tendo também nesse segundo período prejuízo operacional.

A LATAM Airlines resulta da fusão, concretizada em 2012, da organização chilena LAN Airlines com a brasileira TAM Linhas Aéreas, após março de 2016, deixou de ser listada na Bolsa de Valores, Mercadorias e Futuros de São Paulo. Atualmente, essa companhia tem seu capital aberto na Bolsa de Santiago e em Wall Street.

Enquanto a GOL vem se estabelecendo como líder no mercado doméstico de passageiros e, em outubro de 2017, teve uma participação de $35,9 \%$ na demanda de voos domésticos, a LATAM teve uma participação de 33,3\%. Já no mercado internacional é a LATAM a líder entre as concorrentes brasileiras nos últimos anos. No mês de outubro de 2017, obteve uma participação de $71,1 \%$ da demanda de passageiros. Atrás dela estão a Azul, a GOL e a Avianca, nessa ordem (ANAC, 2017).

No que concerne aos novos padrões contábeis de arrendamento mercantil definidos na IFRS 16, a LATAM será uma das empresas afetadas pela mudança. Primeiro, foi necessário acertar seu balanço patrimonial com as quantias referentes ao arrendamento operacional, para os três períodos de estudo, como mostrado na Tabela 3. 
Luíza Lima Najar, José Augusto Veiga da Costa Marques, Marcia da Silva Carvalho \& Leila Batista Mello.

Tabela 3: Balanço Patrimonial da LATAM, com e sem ajustes, dos anos de 2014, 2015 e 2016 (em milhares de reais)

\begin{tabular}{|c|c|c|c|c|c|c|}
\hline LATAM & \multicolumn{2}{|c|}{$2016^{*}$} & \multicolumn{2}{|c|}{2015} & \multicolumn{2}{|c|}{2014} \\
\hline Grupo de Contas & Sem ajuste & Com ajuste & Sem ajuste & Com ajuste & Sem ajuste & Com ajuste \\
\hline Ativo Circulante & 11.787 .019 & 11.787 .019 & 11.022 .864 & 11.022 .864 & 9.654 .283 & 9.654 .283 \\
\hline $\begin{array}{l}\text { Ativo Não } \\
\text { Circulante }\end{array}$ & 50.607 .112 & 61.186 .479 & 59.659 .553 & 70.020 .147 & 44.756 .455 & 50.481 .849 \\
\hline Ativo Total & 62.394 .131 & 72.973 .498 & 70.682 .417 & 81.043 .011 & 54.410 .738 & 60.136 .132 \\
\hline $\begin{array}{l}\text { Passivo } \\
\text { Circulante }\end{array}$ & 20.222 .121 & 21.955 .408 & 22.026 .867 & 24.032 .950 & 15.484 .929 & 16.843 .905 \\
\hline $\begin{array}{l}\text { Passivo Não } \\
\text { Circulante }\end{array}$ & 28.569 .772 & 37.415 .853 & 37.185 .012 & 45.539 .523 & 26.963 .094 & 31.329 .512 \\
\hline $\begin{array}{l}\text { Patrimônio } \\
\text { Líquido }\end{array}$ & 13.602 .238 & 13.602 .238 & 11.470 .538 & 11.470 .538 & 11.962 .715 & 11.962 .715 \\
\hline Passivo Total & 62.394 .131 & 72.973 .498 & 70.682 .417 & 81.043 .011 & 54.410 .738 & 60.136 .132 \\
\hline
\end{tabular}

Fonte: Elaborada pelos autores.

Nota:* Calculado a partir de dados convertidos de dólares para real, segundo a taxa de câmbio de R $\$ 3,25 /$ US\$.

Ao registrar 0 ativo de direito de uso no balanço patrimonial, houve um crescimento no ativo da LATAM em 11\%, 15\% e 17\% nos exercícios de 2014, 2015 e 2016, respectivamente. No trabalho de Barbosa et al. (2011), por sua vez, o aumento do ativo da TAM foi de 18\%, 17\% e 12\% nos anos de 2007, 2008 e 2009, respectivamente.

Quando somados os valores dos pagamentos do arrendamento operacional no passivo exigível, esse último expandiu em 13\%, 17\% e 22\% nos períodos de 2014, 2015 e 2016, nessa ordem. Já na pesquisa tomada como base, esse mesmo grupo de contas ampliou em 22\%, 19\% e 13\% em 2007, 2008 e 2009, respectivamente.

Contrapondo o primeiro ano de observação deste estudo, que envolve a LATAM, com o de Barbosa et al. (2011), que envolve a TAM, e fazendo o mesmo para os demais exercícios, repare que na análise realizada 0 ativo total e o passivo exigível apresentaram um menor crescimento, exceto no último período. Mas, de modo geral, as variações estão próximas umas das outras.

Tabela 4: Indicadores calculados, com e sem ajustes, para a LATAM

\begin{tabular}{|c|c|c|c|c|c|c|}
\hline LATAM & & & & & & \\
\hline Indicadores & Sem ajuste & Com ajuste & Sem ajuste & Com ajuste & Sem ajuste & Com ajuste \\
\hline Liquidez Corrente & 0,583 & 0,537 & 0,500 & 0,459 & 0,623 & 0,573 \\
\hline Grau de Endividamento & 3,587 & 4,365 & 5,162 & 6,065 & 3,548 & 4,027 \\
\hline $\begin{array}{l}\text { Composição do } \\
\text { Endividamento }\end{array}$ & 0,414 & 0,370 & 0,372 & 0,345 & 0,365 & 0,350 \\
\hline $\begin{array}{l}\text { Imobilização do Patrimônio } \\
\text { Líquido }\end{array}$ & 3,541 & 4,318 & 4,950 & 5,853 & 3,545 & 4,024 \\
\hline Retorno sobre o Ativo & 0,024 & 0,021 & 0,023 & 0,021 & 0,025 & 0,023 \\
\hline $\begin{array}{l}\text { Retorno sobre o Patrimônio } \\
\text { Líquido }\end{array}$ & 0,029 & 0,029 & $-0,051$ & $-0,051$ & $-0,040$ & $-0,040$ \\
\hline $\begin{array}{l}\text { Grau de Alavancagem } \\
\text { Financeira }\end{array}$ & 1,191 & 1,378 & $-2,187$ & $-2,468$ & $-1,600$ & $-1,752$ \\
\hline
\end{tabular}

Fonte: Elaborada pelos autores. 
A respeito da liquidez corrente, da composição do endividamento e do retorno sobre 0 ativo, esses índices caíram após os ajustes contábeis do arrendamento operacional, nos três anos de análise, pelos mesmos motivos explicados na seção anterior relativa à organização GOL.

As adaptações do relatório contábil da LATAM levaram em conta os pagamentos totais do arrendamento operacional em seu capital de terceiros, assim como o ativo de direito de uso do bem, sendo esse considerado no ativo permanente da companhia. Todavia, o capital próprio não foi afetado. Tais circunstâncias justificaram o aumento do grau de endividamento e da imobilização do patrimônio líquido para todos os períodos deste estudo, pois para esses dois índices apenas o numerador da fração foi modificado.

Como o patrimônio líquido médio e o lucro líquido da empresa permaneceram inalterados diante dos ajustes feitos, o retorno sobre o patrimônio líquido também continuou com o mesmo resultado em 2016. À vista disso e da redução do retorno sobre o ativo, para esse mesmo exercício social, houve uma elevação do grau de alavancagem financeira. Tanto em 2014 como em 2015, a LATAM obteve prejuízo líquido, o que fez com que não tivesse sentido na compreensão do retorno sobre o patrimônio líquido e, por conseguinte, do grau de alavancagem financeira, para esses anos.

No que concerne à GOL, a comparação deste trabalho com o de Barbosa et al. (2011) foi feito apenas para os indicadores em que foi possível interpretar o impacto dos ajustes contábeis. Ou seja, para os índices de liquidez corrente, composição do endividamento e retorno sobre o ativo, conforme exposto na Tabela 5.

Tabela 5: Variação dos indicadores da GOL, após os ajustes, para o presente estudo e para Barbosa et al. (2011)

\begin{tabular}{lcccccc}
\hline \multicolumn{1}{c}{ GOL } & \multicolumn{2}{c}{ Presente estudo } & \multicolumn{2}{c}{ Estudo de Barbosa et al. (2011) } \\
\hline Indicadores & 2016 & 2015 & 2014 & 2009 & 2008 & 2007 \\
\hline Liquidez Corrente & $-15 \%$ & $-19 \%$ & $-16 \%$ & $-18 \%$ & $-20 \%$ & $-19 \%$ \\
\hline $\begin{array}{l}\text { Composição do } \\
\text { Endividamento }\end{array}$ & $-23 \%$ & $-20 \%$ & $-19 \%$ & $-15 \%$ & $-19 \%$ & $-24 \%$ \\
\hline $\begin{array}{l}\text { Retorno sobre o } \\
\text { ativo }\end{array}$ & $-43 \%$ & $\mathrm{x}$ & $-30 \%$ & $-20 \%$ & $\mathrm{x}$ & $\mathrm{x}$ \\
\hline
\end{tabular}

Fonte: Elaborado pelos autores e adaptado de Barbosa et al. (2011).

Notas:

O sinal negativo significa que após o ajuste houve uma redução no índice em questão.

0 "x" significa que para esses anos não houve comparação entre os trabalhos.

Ao confrontar o primeiro período de avaliação desta pesquisa com o do trabalho de Barbosa et al. (2011), e fazendo o mesmo para os outros anos, os autores do artigo base chegaram a maiores reduções da liquidez corrente. Já com relação à composição do endividamento, foi demonstrada maior diminuição no presente estudo, com exceção do primeiro exercício. De maneira geral, os efeitos sobre esses indicadores foram próximos uns dos outros nas duas pesquisas.

Por outro lado, no que tange ao retorno sobre o ativo, cabe destaque para o terceiro período de observação. Em 2016, esse índice chegou a cair 23\% a mais do que em 2009.

Posto isso, os mesmos procedimentos de comparação realizados para a GOL, foram aplicados para a LATAM e a TAM, no que se refere a este trabalho e ao artigo de Barbosa et al. (2011), respectivamente. Vale lembrar que, para a LATAM, foi possível compreender os efeitos dos ajustes contábeis para todos os indicadores a que este estudo se propôs a discutir. Assim, na Tabela 6 foram relatadas as variações percentuais dos seguintes índices. 
Luíza Lima Najar, José Augusto Veiga da Costa Marques, Marcia da Silva Carvalho \& Leila Batista Mello.

Tabela 6: Variação dos indicadores da LATAM e da TAM, após os ajustes, para o presente estudo e para Barbosa et al. (2011), respectivamente

\begin{tabular}{|c|c|c|c|c|c|c|}
\hline \multirow{2}{*}{$\begin{array}{l}\text { LATAM / TAM } \\
\text { Indicadores }\end{array}$} & \multicolumn{3}{|c|}{ Presente estudo } & \multicolumn{3}{|c|}{ Estudo de Barbosa et al. (2011) } \\
\hline & 2016 & 2015 & 2014 & 2009 & 2008 & 2007 \\
\hline Liquidez Corrente & $-8 \%$ & $-8 \%$ & $-8 \%$ & $-7 \%$ & $-11 \%$ & $-12 \%$ \\
\hline Grau de Endividamento & $+22 \%$ & $+17 \%$ & $+13 \%$ & $+13 \%$ & $+19 \%$ & $+22 \%$ \\
\hline $\begin{array}{l}\text { Composição do } \\
\text { Endividamento }\end{array}$ & $-11 \%$ & $-7 \%$ & $-4 \%$ & $-3 \%$ & $-3 \%$ & $-8 \%$ \\
\hline $\begin{array}{l}\text { Imobilização do } \\
\text { Patrimônio Líquido }\end{array}$ & $+22 \%$ & $+18 \%$ & $+13 \%$ & $+21 \%$ & $+25 \%$ & $+31 \%$ \\
\hline Retorno sobre 0 ativo & $-14 \%$ & $-11 \%$ & $-9 \%$ & $\mathrm{x}$ & $x$ & $x$ \\
\hline $\begin{array}{l}\text { Retorno sobre o } \\
\text { Patrimônio Líquido }\end{array}$ & $0 \%$ & $\mathrm{x}$ & $x$ & $0 \%$ & $x$ & $\mathrm{x}$ \\
\hline $\begin{array}{l}\text { Grau de Alavancagem } \\
\text { Financeira }\end{array}$ & $+16 \%$ & $\mathrm{x}$ & $\mathrm{x}$ & $\mathrm{x}$ & $x$ & $\mathrm{x}$ \\
\hline $\begin{array}{l}\text { Notas: } \\
\text { O sinal positivo significa c } \\
\text { O sinal negativo significa } \\
\text { O "x" significa que para e }\end{array}$ & e: Elabor & $\begin{array}{l}\text { pelos aut } \\
\text { e houve u } \\
\text { te houve }\end{array}$ & e adaptac & $\begin{array}{l}\text { osa et al. } \\
\text { questão } \\
\text { m questã } \\
\text { os. }\end{array}$ & & \\
\hline
\end{tabular}

Ao confrontar o primeiro ano de avaliação desta pesquisa com o de Barbosa et al. (2011), e fazendo o mesmo para o segundo e terceiro períodos, os autores do artigo base chegaram a maiores reduções da liquidez corrente e maiores expansões do grau de endividamento e imobilização do patrimônio líquido, com exceção para o último exercício social. No que diz respeito à composição do endividamento, a queda desse índice foi maior nesta pesquisa, exceto para o primeiro ano.

Apesar dessas diferenças entre os resultados dos dois estudos, de modo geral, os efeitos sobre esses indicadores foram próximos uns dos outros, cabendo duas ressalvas para o primeiro e terceiro períodos de análise. Em 2014, o índice de imobilização do patrimônio líquido subiu 18\% a menos que em 2007. Além disso, nos exercícios de 2009 e de 2016, o retorno sobre o patrimônio líquido não variou.

Ao passo que acerca do retorno sobre o ativo e do grau de alavancagem financeira, da LATAM e da TAM, não foi possível estabelecer um paralelo entre as pesquisas.

Em suma, tanto neste trabalho como no de Barbosa et al. (2011), as alterações que derivaram dos ajustes de arrendamento operacional no balanço patrimonial de cada uma das companhias aéreas, GOL, LATAM e TAM, foram relevantes. 0 que acabou refletindo nos indicadores econômico-financeiros e, em consequência disso, também pode acabar repercutindo significativamente no processo de tomada de decisão do usuário da informação contábil.

Ao analisar o antes e o depois dos ajustes para a GOL, verificou-se uma queda nos índices de liquidez corrente, de composição do endividamento e do retorno sobre o ativo. Para a LATAM, aferiu-se os mesmos efeitos nesses indicadores e mais um aumento no grau de endividamento, na imobilização do patrimônio líquido e no grau de alavancagem financeira. Enquanto o retorno sobre o patrimônio líquido se manteve o mesmo.

Essa tendência de comportamento para a liquidez corrente também foi constatada nos estudos de Bennett e Bradbury (2003), Batista e Formigoni (2013) e Fitó et al. (2013). Quanto ao grau de endividamento, o mesmo impacto também foi observado por Batista e Formigoni (2013), Martins et al. (2013) e Joshi e Wong (2015).

Martins et al. (2013), por sua vez, também apuraram um crescimento para a imobilização do patrimônio líquido. Com relação ao retorno sobre 0 ativo, esse índice também sofreu uma redução nas pesquisas de Bennett e Bradbury (2003), Batista e Formigoni (2013), Fitó et al. (2013) e Joshi e Wong (2015). Em contrapartida, houve dissenso quanto ao retorno sobre o patrimônio líquido, pois de acordo com Batista e Formigoni (2013) esse indicador também não foi modificado, mas para Joshi e Wong (2015) houve diminuição. 
Convém frisar que, da mesma forma como ocorreu no artigo base de Barbosa et al. (2011), para o presente trabalho não houve mudança no denominador dos quocientes do grau de endividamento e da imobilização do patrimônio líquido, pelo fato de não ter sofrido ajustes de depreciação e de juros. 0 mesmo entendimento se aplica para todos os componentes do retorno sobre o patrimônio líquido, bem como para 0 numerador do retorno sobre 0 ativo quanto ao ajuste de depreciação.

Ainda que a pretensão deste estudo não seja correlacionar as empresas GOL e LATAM, mas apenas cada uma delas entre o padrão anterior e o futuro, vale assinalar que a $\mathrm{GOL}$ teve seu ativo ampliado em $37 \%$, $60 \%$ e $57 \%$ a mais que a LATAM em 2014, 2015 e 2016, respectivamente. Quanto ao passivo exigível, foi um crescimento de $34 \%, 36 \%$ e $31 \%$ a mais, nos mesmos períodos. Com isso, os indicadores da GOL também sofreram maior impacto. Principalmente, o retorno sobre o ativo, que em 2014 e 2016 teria sido elevado em $21 \%$ e $29 \%$, nessa ordem, a mais do que para a LATAM.

\section{Considerações finais}

Em geral, todo contrato de arrendamento tem que ser registrado obrigatoriamente nas demonstrações contábeis das arrendatárias, a partir de $1^{\circ}$ de janeiro de 2019. No ativo deve ser contabilizado o direito de uso do bem, enquanto que no passivo são acrescentados os valores de pagamento dessas transações. Já na demonstração do resultado do exercício, têm que ser evidenciadas as despesas de depreciação e de juros.

É natural que companhias que possuam um alto nível de arrendamento operacional, sejam mais afetadas pela alteração dessas práticas contábeis. Como já explicado, as organizações que pertencem ao setor aéreo são algumas das que se encaixam nessa situação.

Esta pesquisa teve como base 0 artigo de Barbosa et al. (2011). Esses autores examinaram as repercussões que a contabilização do arrendamento operacional realizado de modo equivalente à classificação financeira, poderia gerar sobre a estrutura patrimonial das companhias TAM e GOL, nos anos de 2007 a 2009.

A metodologia aplicada para o presente estudo foi a mesma empregada no artigo base, que consistiu em um modelo de ajuste. Foram extraídos das notas explicativas de cada empresa os saldos referentes ao arrendamento operacional. Em seguida, nos três períodos de análise, passaram a ser levados em consideração no balanço patrimonial da GOL e da LATAM, os montantes de pagamentos futuros de arrendamento operacional de curto e longo prazo, respectivamente, no passivo circulante e não circulante, ao passo que no ativo não circulante foi somado o valor total dessas obrigações. A partir disso, foram calculados, para as duas organizações, determinados indicadores econômico-financeiros, antes e depois dessas adaptações.

Observou-se que, após os ajustes, os anos de maior impacto para o balanço da GOL foram os de 2015 e 2016. Seu ativo total cresceu em $75 \%$ e $74 \%$ nesses períodos, e seu passivo exigível aumentou em $53 \%$ em ambos os exercícios.

Com relação ao relatório contábil da LATAM, o ano de 2016 foi o mais notável, com uma elevação de $17 \%$ e $22 \%$ em seu ativo e passivo, respectivamente.

No que diz respeito aos índices calculados, comparando o padrão anterior e o padrão futuro para a GOL, foi possível perceber uma redução na liquidez corrente, na composição do endividamento e no retorno sobre o ativo. Cabe destaque para a queda de $19 \%$ da liquidez corrente em 2015, e para as diminuições de 23\% e 43\% para a composição do endividamento e retorno sobre o ativo, respectivamente, em 2016.

A LATAM, por sua vez, além de sofrer um decréscimo nesses indicadores mencionados, também teve seu grau de endividamento, imobilização do patrimônio líquido e grau de alavancagem financeira, majorados, enquanto o retorno sobre o patrimônio líquido permaneceu inalterado. Os impactos mais evidentes foram para o grau de endividamento e imobilização do patrimônio líquido, com uma expansão de $17 \%$ e 18\%, respectivamente, em 2015. Já em 2016, para ambos houve um crescimento de $22 \%$. 
Tanto neste trabalho como no artigo base de Barbosa et al. (2011), a inclusão do arrendamento operacional no balanço patrimonial de cada uma das companhias aéreas, gerou efeitos expressivos. Assim, 0 mesmo ocorreu para os indicadores econômico-financeiros, o que pode influenciar significativamente na tomada de decisão dos usuários da informação contábil, como já explicado anteriormente.

É importante ressaltar que antes mesmo da edição da IFRS 16, em estudos como os apreciados a seguir e que também foram abordados na seção de Contribuições e Pesquisas Recentes, os autores avaliaram, dentre outros aspectos, os reflexos, que uma alteração da contabilização do arrendamento mercantil, poderiam causar nos indicadores econômico-financeiros de arrendatárias na modalidade operacional.

Esse é o caso, por exemplo, de Bennett e Bradbury (2003), Batista e Formigoni (2013) e Fitó et al. (2013), que também observaram uma redução para a liquidez corrente, ao adicionar os valores relativos ao arrendamento operacional nas demonstrações contábeis das arrendatárias. A respeito do grau de endividamento, também foi constatado por Batista e Formigoni (2013), Martins et al. (2013) e Joshi e Wong (2015), um aumento desse índice.

A tendência de crescimento para a imobilização do patrimônio líquido também foi conferida por Martins et al. (2013). Quanto ao retorno sobre o ativo, os estudos de Bennett e Bradbury (2003), Batista e Formigoni (2013), Fitó et al. (2013) e Joshi e Wong (2015), também apontaram uma queda para esse indicador, inclusive, no que concerne ao retorno sobre o patrimônio líquido se manter o mesmo, isso também foi sustentado por Batista e Formigoni (2013). No entanto, no trabalho de Joshi e Wong (2015) foi verificada uma diminuição nesse índice.

Portanto, percebe-se que todos esses resultados confirmaram, sobretudo, quanto à transparência de informações, a importância de se reconhecer no balanço patrimonial da arrendatária, o bem arrendado e as obrigações de pagamentos referentes ao arrendamento operacional. Com a IFRS 16, isso passa a ser concretizado, o que pode acabar gerando consequências significativas tanto para a empresa, como para 0 usuário da informação.

Para futuras pesquisas, recomenda-se a avaliação dos efeitos da IFRS 16, também sobre a demonstração do resultado do exercício das arrendatárias, que estão sob a modalidade operacional, tendo em vista que o reconhecimento das despesas de depreciação e de juros afetaria o lucro ou prejuízo líquido da organização e, por conseguinte, o seu patrimônio líquido.

\section{Referências}

Agência Nacional De Aviação Civil. (2017). Demanda e Oferta do Transporte Aéreo: Empresas Brasileiras. Brasília: ANAC. Recuperado em 4 dezembro, 2017, de http://www.anac.gov.br/assuntos/dados-e-estatisticas/demanda-e-oferta-do-transporteaereo

Barbosa, G. de C., Barros, F. de O., Niyama, J. K., \& Souza, L. de M. (2011). Impacto da contabilização do leasing operacional no balanço patrimonial: o caso das Cias. aéreas brasileiras TAM e GOL. Enfoque: Reflexão Contábil, 30 (1), 21-34. doi: 10.4025/enfoque.v30i1.13178.

Batista, E. B. de O., \& Formigoni, H. (2013). Arrendamento Mercantil Operacional: as mudanças propostas pelos organismos internacionais e seus efeitos nas empresas brasileiras. Revista Evidenciação Contábil \& Finanças, 1 (2), 22-37. doi: 10.18405/recfin20130202.

Bennett, B. K., \& Bradbury, M. E. (2003). Capitalizing Non-cancelable Operating Leases. Journal of International Financial Management \& Accounting, 14 (2), 101-114. doi: 10.1111/1467-646X.00091.

Beuren, I. M. (Org.) (2013). Como Elaborar Trabalhos Monográficos em Contabilidade: Teoria e Prática. São Paulo: Editora Atlas.

Comitê De Pronunciamentos Contábeis. (2010). Pronunciamento Técnico CPC 06 (R1): Operações de Arrendamento Mercantil. Brasília: CPC. Recuperado em 15 outubro, 2016, de http://static.cpc.aatb.com.br/Documentos/163_CPC_06_R1_rev\%2008.pdf 
Deloitte Touche Tohmatsu Limited. (2016a). NIIF 16 Arrendamientos: Lo que hay que saber sobre cómo van a cambiar los arrendamientos. [S.I.]: Deloitte. Recuperado em 2 dezembro, 2017, de https://www2.deloitte.com/content/dam/Deloitte/es/Documents/auditoria/Deloitte_ES_Auditoria_NIIF-16-arrendamientos.pdf

Deloitte Touche Tohmatsu Limited. (2016b). Leases: A guide to IFRS 16. Londres: Deloitte. Recuperado em 2 dezembro, 2017, de https://www2. deloitte.com/content/dam/Deloitte/sg/Documents/audit/sea-audit-IFRS-16-guide.pdf

Díaz, J. M. (2016). La nueva revolución en la contabilidad de los arrendamentos. Efectos contables y económicos. Revista Contable, 5 (43), 8-24. Recuperado em 30 setembro, 2016, de https://aeca.es/old/new/2016/comunicacion11.pdf

Duke, J. C., Hsieh, S.-J., \& Su, Y. (2009). Operating and synthetic leases: Exploiting financial benefits in the post-Enron era. Advances in Accounting, incorporating Advances in International Accounting, 25, 28-39. doi:10.1016/j.adiac.2009.03.001.

EYGM Limited. (2016). Good Group International GAAPC: Demonstrações financeiras consolidadas ilustrativas em IFRS, referentes ao exercício findo em 31 de dezembro de 2015, baseadas nos pronunciamentos técnicos emitidos pelo Comitê de Pronunciamentos Contábeis - CPC. [S.I.]: EY. Recuperado em 24 julho, 2017, de http://cdn.ey.com/Good_Group2016/files/assets/common/downloads/publication.pdf

Fitó, M. À., Moya, S., \& Orgaz, N. (2013). Considering the effects of operating lease capitalization on key financial ratios. Revista Española de Financiación y Contabilidad, 42 (159), 341-369. Recuperado em 1 outubro, 2016, de https://aeca.es/old/refc_19722013/2013/159-3.pdf

Gil, A. C. (2008). Métodos e Técnicas de Pesquisa Social. São Paulo: Editora Atlas.

Imhoff, E. A., Lipe, R. C., \& Wright, D. W. (1991). Operating Leases: Impact of Constructive Capitalization. Accounting Horizons, 5 (1), 51-63.

Imhoff, E. A., Lipe, R. C., \& Wright, D. W. (1993). The Effects of Recognition versus Disclosure on Shareholder Risk and Executive Compensation. Journal of Accounting, Auditing \& Finance, 8 (4), 335-368.

Imhoff, E. A., Lipe, R. C., \& Wright, D. W. (1995). Is Footnote Disclosure an Adequate Alternative to Financial Statement Recognition? Journal of Financial Statement Analysis, 70-81.

Imhoff, E. A., Lipe, R. C., \& Wright, D. W. (1997). Operating leases: Income Effects of Constructive Capitalization. Accounting Horizons, $11(2), 12-32$.

International Financial Reporting Standard Foundation. (2016a). Effects Analysis: IFRS 16 Leases. Londres: IFRS Foundation. Recuperado em 16 outubro, 2016, de http://www.ifrs.org/-/media/project/leases/ifrs/published-documents/firs16-effectsanalysis.pdf

International Financial Reporting Standard Foundation. (2016b). IASB shines light on leases by bringing them onto the balance sheet. [S.I.]: IFRS Foundation. Recuperado em 24 julho, 2017, de http://www.ifrs.org/news-and-events/2016/01/iasb-shines-light-onleases-by-bringing-them-onto-the-balance-sheet/

ludícibus, S. de, Martins, E., Gelbcke, E. R., \& Santos, A. dos. (2010). Manual de Contabilidade Societária: Aplicável a todas as sociedades de acordo com as Normas Internacionais e do CPC. São Paulo: Editora Atlas.

Joshi, M., \& Wong, K. (2015). The Impact of Lease Capitalisation on Financial Statements and Key Ratios: Evidence from Australia. Australasian Accounting, Business and Finance Journal, 9 (3), 27-44. doi:10.14453/aabfj.v9i3.3.

KPMG International Standards Group. (2016). IFRS 16 Arrendamentos: Um balanço mais transparente. Tradução KPMG Auditores Independentes. [S.I.]: KPMG. Recuperado em 11 julho, 2017, de https://assets.kpmg.com/content/dam/kpmg/pdf/2016/04/br-ifrsem-destaque-02-2016.pdf

Lei nº 6.404, de 15 de dezembro de 1976. (1976, 17 de dezembro). Dispõe sobre as Sociedades por Ações. Diário Oficial da União. Brasilia, DF: Presidência da República.

Lei no 11.638, de 28 de dezembro de 2007. (2007, 28 de dezembro). Altera e revoga dispositivos da Lei no 6.404, de 15 de dezembro de 1976, e da Lei no 6.385, de 7 de dezembro de 1976, e estende às sociedades de grande porte disposições relativas à elaboração e divulgação de demonstrações financeiras. Diário Oficial da União. Brasilia, DF: Presidência da República.

Lipe, R. C. (2001). Lease Accounting Research and the G4+1 Proposal. Accounting Horizons, 15 (3), 299-310. doi: 10.2308/acch.2001.15.3.299.

Lloyd, S., Kabureck, G., Scott, D., \& Cooper, S. (2017). Leases one year on-putting IFRS 16 into practice. [S.I.]: IFRS Foundation. Recuperado em 24 julho, 2017, de http://www.ifrs.org///media/project/leases/frss/educational-materials/fifs 16-leases-articlejan2017.pdf

Machado, M. R., Machado, M. A. V., \& Martins, V. G. (2013). Value Relevance das informações de Leasing Operacional: um estudo em empresas brasileiras. Enfoque: Reflexão Contábil, 32 (2), 83-99. doi: 10.4025/enfoque.v32i2.19762. 
Martins, V. G., Silva Filho, A. C. da C., Girão, L. F. de A. P., \& Niyama, J. K. (2013). Reflexos da Capitalização do Leasing Operacional nos Indicadores de Estrutura de Empresas do Subsetor de Transportes Listadas na Bovespa. Sociedade, Contabilidade e Gestão, 8 (3). Recuperado em 26 setembro, 2016, de http://www.atena.org.br/revista/ojs-2.2.3-06/index.php/ufrj/article/viewFile/1936/1770

Oxford Economics. (2016). A Importância do Transporte Aéreo no Brasil. Patrocínio: Associação Internacional do Transporte Aéreo. Londres: Oxford Economics. Recuperado em 2 setembro, 2017, de https://www.iata.org/policy/Documents/benefits-of-aviationbrazil-2017-portuguese.pdf

Richardson, R. J. (2012). Pesquisa Social: Métodos e Técnicas. São Paulo: Editora Atlas.

Securities and Exchange Commission. (2005). Report and Recommendations Pursuant to Section 401(c) of the Sarbanes-Oxley Act of 2002 On Arrangements with Off-Balance Sheet Implications, Special Purpose Entities, and Transparency of Filings by Issuers. [S.I.]: SEC. Recuperado em 15 outubro, 2016, de https://www.sec.gov/news/studies/soxoffbalancerpt.pdf.

\section{DADOS DOS AUTORES}

\section{Luíza Lima Najar}

Graduada em Ciências Contábeis pela FACC/UFRJ

Endereço: Av. Pasteur, 250 - Urca

CEP: 22.290-240 - Rio de Janeiro/RJ - Brasil

E-mail: luizalnajar@gmail.com

Telefone: (21) 98347-1862

\section{José Augusto Veiga da Costa Marques}

Professor Titular do Programa de Pós-Graduação em Ciências Contábeis da UFRJ

Endereço: Av. Pasteur, 250 - sala 251 - Urca

CEP: 22.290-240 - Rio de Janeiro/RJ - Brasil

E-mail: joselaura@uol.com.br

Telefone: (21) 99272-7378

\section{Marcia da Silva Carvalho}

Professora Adjunta do Programa de Pós-Graduação em Ciências Contábeis da UFRJ

Endereço: Av. Pasteur, 250 - sala 250/Mezanino - Urca

CEP: 22.290-240 - Rio de Janeiro/RJ - Brasil

E-mail: marcia@facc.ufrj.br

Telefone: (21) 97119-0309

\section{Leila Batista Mello}

Doutoranda no Programa de Pós-Graduação em Ciências Contábeis da UFRJ

Endereço: Av. Pasteur, 250 - sala 250 - Urca

CEP: 22.290-240 - Rio de Janeiro/RJ - Brasil

E-mail: leilalbm63@gmail.com

Telefone: (21) 98104-2577 
Principais impactos da Nova Norma Internacional de Arrendamento Mercantil sobre os indicadores econômico-financeiros das empresas aéreas GOL e LATAM.

\section{Contribuição dos Autores:}

\begin{tabular}{lcccc}
\hline Contribuiç̧ão & Luíza Najar & $\begin{array}{c}\text { José } \\
\text { Marques }\end{array}$ & $\begin{array}{c}\text { Marcia } \\
\text { Carvalho }\end{array}$ & Leila Mello \\
\hline 1. Concepção do assunto e tema da pesquisa & $\sqrt{ }$ & & \\
2. Definição do problema de pesquisa & $\sqrt{ }$ & $\sqrt{ }$ & \\
3. Desenvolvimento das hipóteses e constructos da & $\sqrt{ }$ & $\sqrt{ }$ & \\
pesquisa (trabalhos teórico-empíricos) & & & \\
4. Desenvolvimento das proposições teóricas & & & \\
(trabalhos teóricos os ensaios teóricos) & $\sqrt{ }$ & $\sqrt{ }$ & \\
5. Desenvolvimento da plataforma teórica & $\sqrt{ }$ & $\sqrt{ }$ & \\
6. Delineamento dos procedimentos metodológicos & $\sqrt{ }$ & & \\
7. Processo de coleta de dados & $\sqrt{ }$ & & \\
8. Análises estatísticas & $\sqrt{ }$ & & $\sqrt{ }$ \\
9. Análises e interpretações dos dados coletados & $\sqrt{ }$ & $\sqrt{ }$ & \\
10. Considerações finais ou conclusões da pesquisa & $\sqrt{ }$ & & $\sqrt{ }$ \\
11. Revisão crítica do manuscrito & $\sqrt{ }$ & & \\
12. Redação do manuscrito & & & \\
\hline
\end{tabular}

